\title{
GENETIC DIVERSITY OF BRAZILIAN PEPPER BASED ON QUALITATIVE REPRODUCTIVE TRAITS
}

\author{
Gabriel Mascarenhas Maciel ${ }^{1}$, Fábio Janoni Carvalho², Camila Soares de Oliveira², Lucas Medeiros \\ Pereira $^{3}$, Aline José da Silveira ${ }^{3}$, Igor Forigo Beloti ${ }^{2 *}$
}

\author{
${ }^{1}$ Professor, Instituto de Ciências Agrárias, Universidade Federal de Uberlândia campus Monte Carmelo (UFU), km 1, LMG-746, Monte \\ Carmelo/MG-CEP: $38500-000$ \\ 2Doutorandos em Agronomia, Programa de Pós graduação em Agronomia, Instituto de Ciências Agrárias, Universidade Federal de \\ Uberlândia (UFU), BR-050, km 78, Uberlândia/MG-CEP: 38410-337 \\ ${ }^{3}$ Graduandos em Agronomia, Instituto de ciências Agrárias, Universidade Federal de Uberlândia campus Monte Carmelo (UFU), km 1 , \\ LMG-746, Monte Carmelo/MG-CEP: 38500-000 \\ *Autor para correspondência: Igor ForigoBeloti, agroifb@gmail.com
}

\begin{abstract}
In Brazil, pepper cultivation gives producers more marketing opportunities in various segments, either for fresh consumption or industry. Reproductive traits are efficient methods for comparing genetic divergence in pepper, once most differences among accessions could be verified at this stage. This study aimed to evaluate the genetic divergence in the reproductive phase of pepper accessions by multivariate analysis and test the efficiency of different methods. Sixty-five genotypes from the Federal University of UberlândiaCapsicum spp. Germplasm Bank were evaluated 145 days after sowing, and morphological characterization was performed at reproductive phase. Graphical representation of genetic distances was obtained by UPGMA. Tocher optimization method was also used to group accessions. Genotypes were arranged in seventeen different groups by Tocher method. UPGMA dendrogram collaborated with Tocher method, indicating the wide genetic variability of genotypes. Tocher and UPGMA methods were partially in agreement, allowing grouping 44 of the 65 analyzed accessionsequally. Multicategorical traits have the advantage of easy observation and require less time and labor, being ideal for use in gene bank and collections that do not have high human and financial resources. Moreover, these traits are not affected by the environment. Genetic divergence detected in this paper encourages other researchers to perform the characterization of pepper collections as completely as possible, because it becomes possible to generate more reliable information of the variability and genetic divergence among accessions. Our research discloses the reproductive biodiversity of pepper in "Alto Paranaíba" and "TriânguloMineiro" regions and the importance of maintaining these genotypes.
\end{abstract}

KEYWORDS: Capsicum spp.;Active germplasm bank;Multivariate clustering analysis; Multicategorical traits; Pepper breeding programs.

\section{DIVERSIDADE GENÉTICA DE PIMENTAS BRASILEIRAS COM BASE EM CARACTERES REPRODUTIVOS QUALITATIVOS}

RESUMO: O cultivo de pimentas no Brasil permite maiores oportunidades de mercado em vários segmentos aos produtores, seja in natura ou para indústria. Caracteres reprodutivos são métodos eficientes para comparação da diversidade genética das pimentas, uma vez que muita das diferenças entre acessos pode ser verificada neste estágio. $\mathrm{O}$ estudo objetivou avaliar a diversidade genética na fase reprodutiva em acessos de pimenta pela análise multivariada e testar a eficiência destes métodos. Sessenta e cinco genótipos do banco de germoplasma de Capisicum spp da Universidade Federal de Uberlândia, foram avaliados. Cento e quarenta e cinco dias após semeadura, a caracterização morfológica foi realizada na fase reprodutiva. A representação gráfica dos genótipos foi obtida pelo método UPGMA. 0 método de otimização de Tocher foi também empregado para agrupamento dos acessos. Os genótipos foram agrupados em 17 grupos pelo método de otimização de Tocher. 0 dendrograma de UPGMA corroborou com os resultados do agrupamento de Tocher, indicando alta variabilidade genética entre os genótipos. Os agrupamentos formados pelo método de Tocher e UPGMA foram parcialmente de acordo, agrupando igualmente 44 dos 65 genótipos analisados. Caracteres multicategóricos possuem a vantagem de 
fácil observação e requerem menos tempo e trabalho, sendo ideais para uso em bancos genéticos e coleções que não possuem muitos recursos financeiros ou mão-de-obra. Além disso, estes caracteres praticamente não sofrem variação ambiental. A diversidade genética detectada neste trabalho representa estímulo para outros pesquisadores realizarem a caracterização de suas coleções de forma mais completa, permitindo a geração de informações mais precisas sobre a variabilidade e divergência genética entre seus acessos. A pesquisa revela a biodiversidade de pimentas nas regiões do Alto Paranaíba e Triângulo Mineiro e a importância da manutenção destes genótipos.

PALAVRASCHAVE: Capsicum spp.; Banco de germoplasma ativo; Análise de agrupamento multivariada; Caracteres multicategóricos; Melhoramento de pimentas.

\section{INTRODUCTION}

Pepper belongs to the genus Capsicum and family Solanaceae. It is estimated that the world's Capsicum production is over 30 million tons in almost four million hectares. India is the major producer and consumer (Faostat, 2016). In Brazil, pepper cultivation gives producers more marketing opportunities in various segments, either for fresh consumption or industry(Signorini et al., 2013). The importance of pepper cultivation is directly associated with its consumption, being considered one of the most important species used by family farmers (Costa et al., 2015; Signorini et al., 2013). According to ABCSEM (2016), more than $3,322 \mathrm{~kg}$ of pungent and not pungent hot pepper seeds were sold in Brazil in 2011, with an estimate of 2,460 ha planted area.

However, unlike other countries with higher productions, pepper cultivation in Brazil is restricted to low diversity of varieties available to farmers, mostly occurring with informal marketing. In addition, with the growth of large urban centers, of the number of small farmershas reduced, resulting in the extinction of many Capsicum genotypes, narrowing the genetic base (Domenico et al., 2012). Several researches onCapsicum have evaluated aspects related to fruit productivity (Büttow et al., 2010; Domenico et al., 2012; Moura et al., 2010; Paulus et al., 2015), but there is little database with descriptions of reproductive features in a pepper germplasm. Reproductive traits are efficient methods for comparing genetic divergence in pepper, once most differences among accessions could be verified at this stage (Bianchi et al., 2016). Qualitative traits are little influenced by the environment, allowing an efficiency genetic distinction among accessions. Furthermore, classification is simpler and faster compared to quantitative methods, and several qualitative descriptors have already been proposed for the species (IPGRI, 1995).

Efficient description of accessions in a gene bank can define the future of the genetic diversity of a species (Costa et al., 2015). In Brazil, few studies had reported the genetic diversity of pepper, compromising the possibility of interesting crosses for plant breeding. Moreover, there is no consensus regarding the best multivariate analysis method able to characterize the reproductive phase of Capsicum spp. accessions. Therefore, this study aimed to evaluate the genetic divergence in the reproductive phase of pepper accessions by multivariate analysis and test the efficiency of different methods.

\section{MATERIAL AND METHODS}

Sixty-five genotypes from the Capsicum spp. Germplasm Bank were evaluated at the Federal University ofUberlândia-UFU, Campus of Monte Carmelo, MG, Brazil (Table 1). Currently, the bank has 250 accessions that have been acquired through donation, collection and purchase in farmer's markets. All analyses were conducted at the Laboratory of Seed and Genetic Resource Analysis, UFU (LAGEN). This genetic bank includes part of the pepper biodiversity of "Alto Paranaíba" and "TriânguloMineiro" regions of Minas Gerais that is home of small-scale pepper producers.

The experiment was conducted at the Horticultural Experiment Station, (18042'43"S, $47^{\circ} 29^{\prime} 55^{\prime \prime} \mathrm{W}$ and 873 ma.s.l., humid temperate climate with hot summers and dry winters). Sowing was performed on September of 2013, in 128-cell polystyrene trays filled with commercial coconut-fiber substrate. After sowing, trays were kept in gableroofed greenhouse covered by transparent 150-micron polyethylene film activated against ultraviolet rays with $30 \%$ shade. Seedlings were transplanted 54 days after sowing, with twenty seedlings of each accession planted in four rows, spaced one meter between lines and 0.7 meter between plants, with total experimental area of $1,316 \mathrm{~m}^{2}$. Four replicates of each accession were planted in a randomized block design (RBD). 
Table 1. Location of accessions used in theCapsicum spp. gene Bank of the Federal University of Uberlândia. Monte Carmelo, UFU, 2016.

\begin{tabular}{|c|c|c|c|c|c|}
\hline Accession & Location & Species & Accession & Location & Species \\
\hline UFU 02 & Estrela do Sul & C. chinense & UFU 41 & Estrela do Sul & C. chinense \\
\hline UFU 03 & Estrela do Sul & C. baccatum & UFU 42 & Monte Carmelo & C. chinense \\
\hline UFU 04 & Monte Carmelo & C. annuum & UFU 43 & Monte Carmelo & C. chinense \\
\hline UFU 05 & Gonçalves & C. frutescens & UFU 44 & Monte Carmelo & C. frutescens \\
\hline UFU 06 & Celso Bueno & C. chinense & UFU 45 & Estrela do Sul & C. baccatum \\
\hline UFU 07 & Monte Carmelo & C. chinense & UFU 47 & Estrela do Sul & C. baccatum \\
\hline UFU 08 & Monte Carmelo & C. baccatum & UFU 48 & Penedo & C. baccatum \\
\hline UFU 09 & Brejão & C. baccatum & UFU 49 & Monte Carmelo & C. baccatum \\
\hline UFU 10 & Gonçalves & C. chinense & UFU 50 & Monte Carmelo & C. chinense \\
\hline UFU 11 & Gonçalves & C. baccatum & UFU 51 & Monte Carmelo & C. chinense \\
\hline UFU 14 & Brejão & C. chinense & UFU 52 & Monte Carmelo & C. chinense \\
\hline UFU 15 & Brejão & C. chinense & UFU 53 & Monte Carmelo & C. chinense \\
\hline UFU 16 & ÁguaEmendada & C. baccatum & UFU 54 & Monte Carmelo & C. chinense \\
\hline UFU 17 & Penedo & C. baccatum & UFU 55 & Celso Bueno & C. chinense \\
\hline UFU 18 & Penedo & C. baccatum & UFU 56 & Chapada & C. chinense \\
\hline UFU 19 & Brejão & C. chinense & UFU 57 & Tijuca & C. chinense \\
\hline UFU 21 & Brejão & C. chinense & UFU 58 & ÁguaEmendada & C. chinense \\
\hline UFU 22 & Monte Carmelo & C. chinense & UFU 59 & São Félix & C. baccatum \\
\hline UFU 23 & ÁguaEmendada & C. chinense & UFU 60 & Matheus & C. chinense \\
\hline UFU 24 & ÁguaEmendada & C. chinense & UFU 61 & Capão Alto & C. baccatum \\
\hline UFU 25 & Gamas & C. baccatum & UFU 62 & Capão Alto & C. chinense \\
\hline UFU 26 & ÁguaEmendada & C. chinense & UFU 63 & Estrela do Sul & C. chinense \\
\hline UFU 27 & Perdizes & C. baccatum & UFU 64 & Capão Alto & C. chinense \\
\hline UFU 30 & Perdizes & C. chinense & UFU 65 & Monte Carmelo & C. chinense \\
\hline UFU 31 & São Félix & C. baccatum & UFU 66 & São Félix & C. chinense \\
\hline UFU 32 & Perdizes & C. baccatum & UFU 67 & Monte Carmelo & C. chinense \\
\hline UFU 33 & Perdizes & C. baccatum & UFU 68 & ÁguaEmendada & C. chinense \\
\hline UFU 34 & Perdizes & C. chinense & UFU 69 & Monte Carmelo & C. chinense \\
\hline UFU 35 & ÁguaEmendada & C. chinense & UFU 72 & Gamas & C. chinense \\
\hline UFU 36 & ÁguaEmendada & C. chinense & UFU 73 & Gamas & C. chinense \\
\hline UFU 37 & Perdizes & C. chinense & UFU 74 & Monte Carmelo & C. chinense \\
\hline UFU 38 & Perdizes & C. chinense & UFU 75 & Tijuca & C. chinense \\
\hline UFU 39 & Estrela do Sul & C. chinense & & & \\
\hline
\end{tabular}

Before transplanting, the experimental site was prepared by harrowing and disking, both twice. Soil had the following characteristics: $\mathrm{pH}\left(\mathrm{H}_{2} \mathrm{O}\right)=5.9$; available $\mathrm{P}=30.1 \mathrm{mg} \cdot \mathrm{dm}^{-3} ; \mathrm{K}^{+}=0.22 \mathrm{cmolc} \cdot \mathrm{dm}^{-3} ; \mathrm{Ca}^{+2}=2.8$ cmolc. $\mathrm{dm}^{-3} ; \mathrm{Mg}^{+2}=1.0 \mathrm{cmolc} . \mathrm{dm}^{-3}$; exchangeable $\mathrm{H}+$ $\mathrm{Al}=3.40 \mathrm{cmolc} \mathrm{dm}^{-3}$; organic matter $=4.2 \mathrm{dag} \mathrm{Kg}^{-1}$; $\mathrm{SMP}=3.40 ; \mathrm{Al}^{+3}=0.0 \mathrm{cmolc}^{+\mathrm{dm}^{-3}} ; \mathrm{CEC} \mathrm{pH} 7.0=7.42$ cmolc. $\mathrm{dm}^{-3}$; CEC base saturation $(\mathrm{pH} 7.0)=54 \% ; \mathrm{Al}$

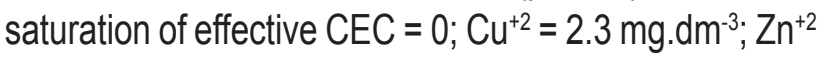
$=6.6 \mathrm{mg} \cdot \mathrm{dm}^{-3}$ and $\mathrm{Mn}^{+2}=6.6 \mathrm{mg} \cdot \mathrm{dm}^{-3}$. Crop treatments were performed as recommended for pepper. One hundred forty-fivedays after sowing, morphological characterization was performed at reproductive phase, according to Capsicum descriptors (IPGRI, 1995). Genetic dissimilarity matrix based on these multicategorical variables was estimated by Gower's algorithm (1971), since this technique is efficient to simultaneously analyze quantitative and qualitative data, or only qualitative data (Moura et al., 2010). Dissimilarity among genotypes was expressed as:

$$
S_{i j k}=\frac{\sum_{k=1}^{p} W_{i j k} \cdot S_{i j k}}{\sum_{k=1}^{p} W_{i j k}}
$$

where: $k$ is the number of variables $(k=1,2, \ldots, p)$; $i$ and $j$ are two individuals representing accessions; $W_{i j k}$ is the weight given to ijk comparison ( 1 for valid comparisons and 0 for invalid comparisons); $S_{i j k}$ is the variable contribution ofk in the similarity between $i$ and $j$ individuals.

Graphical representation of genetic distances was obtained by Unweighted Pair-Group Method using Arithmetic Average (UPGMA). The NbClust package from the $R$ software was used to determine the best number of clusters, based on 24 indexes that establish the compactness and separation criteria among clusters. Tocher optimization method was also established to group accessions. Cophenetic correlation coefficient (CCC) was performed for UPGMA and Tocher methods to identify the clustering quality of both. 
Mean Decrease Impurity (MDI) was measured to evaluate the importance of variables and Cramer's V measured the correlation among traits with Chi-Square test $\left(x^{2}\right)$ to validate correlations, with 0.05 significance. Data were analyzed with $\mathrm{R}$ software, using clusters packages to estimate dissimilarity matrix, random Forest to measure MDI (Liaw and Wiener, 2002); NbClust for the number of clusters (Charrad et al., 2014); stats for UPGMA, its CCC and Pearson's Chi-Square; biotools for Tocher and its CCC (Silva and Dias, 2013). Graphic artwork was performed with the SigmaPlot $₫$ software (version 11.0).

\section{RESULTS AND DISCUSSION}

From the 16 evaluated traits, only seed color did not change among genotypes, being all categorized with yellow seeds. This variable also did not differ among 40 pepper accessions from Amazonas-Brazil, studied by Costa et al. (2015). The other 15 traits were capable of detecting genetic divergence among accessions. Vasconcelos et al. (2012) also obtained efficient distinction among 22 Capsicum chinense accessions, with ten qualitative descriptors used in our work.
Gower's algorithm was capable of detecting divergence among genotypes. This methodology was widely used in dissimilarity papers with qualitative and quantitative traits (Silva et al., 2016), including pepper (Moura et al., 2010; Costa et al., 2015). However, Knezovic et al. (2005) warned that this approach is not suitable, because the distance between two accessions will immediately be 0 or 1 ; but also, questionable, because variables will be unequally weighted, where in a multi-level situation, more weight will be given to variables with more levels, while on a single level incompatibilities will outweigh correspondences.

Genotypes were arranged in 17 different groups by the Tocher optimization method (Table 2), showing that these descriptors were efficient to detect genetic divergence in Capsicum accessions, justified by the large variability at reproductive stage for that genus. Six clusters had only one genotype. Other five clusters had two genotypes. These clusters could be used to search genotypes with different traits to improve genetic diversity among crosses. On the other hand, if the aim of crossingsis to keep high fruit quality (for example, dark red fruit and small seeds), Group 1 and 2 detected large number of genotypes that would be recommended for that case.

Table 2. Clustering of 65 Capsicum accessions by the Tocher optimization procedure obtained from reproductive traits. Monte Carmelo, UFU, 2016.

\begin{tabular}{cc}
\hline Group 1 & $\begin{array}{r}\text { UFU-22 UFU-51 UFU-27 UFU-30 UFU-72 UFU-56 UFU-57 UFU-58 UFU-62 UFU-31 UFU-14 UFU-44 } \\
\text { UFU-68 UFU-50 UFU-61 UFU-63 UFU-19 UFU-26 UFU-65 }\end{array}$ \\
\hline Group 2 & UFU-25 UFU-59 UFU-02 UFU-60 UFU-23 UFU-45 UFU-21 UFU-49 UFU-24 \\
\hline Group 3 & UFU-05 UFU-41 UFU-38 UFU-09 UFU-18 UFU-07 \\
\hline Group 4 & UFU-15 UFU-73 UFU-74 UFU-36 UFU-03 UFU-55 \\
\hline Group 5 & UFU-42 UFU-67 UFU-66 UFU-08 UFU-06 UFU-39 \\
\hline Group 6 & UFU-33 UFU-34 UFU-11 \\
\hline Group 7 & UFU-10 UFU-53 \\
\hline Group 8 & UFU-48 UFU-52 \\
\hline Group 9 & UFU-16 UFU-54 \\
\hline Group 10 & UFU-17 UFU-47 \\
\hline Group 11 & UFU-43 UFU-64 \\
\hline Group 12 & UFU-04 \\
\hline Group 13 & UFU-32 \\
\hline Group 14 & UFU-35 \\
\hline Group 15 & UFU-37 \\
\hline Group 16 & UFU-69 \\
\hline Group 17 & UFU-75 \\
\hline
\end{tabular}


UPGMA dendrogram collaborated with the Tocher method, indicating the wide genetic variability of genotypes (Figure 1). Thirteen of the 24 indexes from $\mathrm{NbClust} \mathrm{package} \mathrm{indicated} \mathrm{ideal} \mathrm{formation} \mathrm{of} 15$ clusters for the data, which helped for the cut of $37.3 \%$ of similarity on the graphic, generating 14 different groups. UPGMA also isolated UFU-35, UFU-69, UFU-32, UFU-04 and UFU-75. UFU-48 and UFU-10 genotypes once they were paired with other genotypes at Tocher's optimization. UFU-37, isolated at Tocher's, was grouped with UFU-39, UFU-54 and UFU-68, showing to be genotypes with close phenotyping in relation to UFU-37. Larger clusters had 20 and 13 genotypes, respectively, showing that UPGMA created larger groups than Tocher.

Figure 1. Cluster dendrogram from the Unweighted Pair-Group Method using the Arithmetic Average (UPGMA) method of 65 Capsicum accessions using Gower's algorithm matrix. Monte Carmelo, UFU, 2016

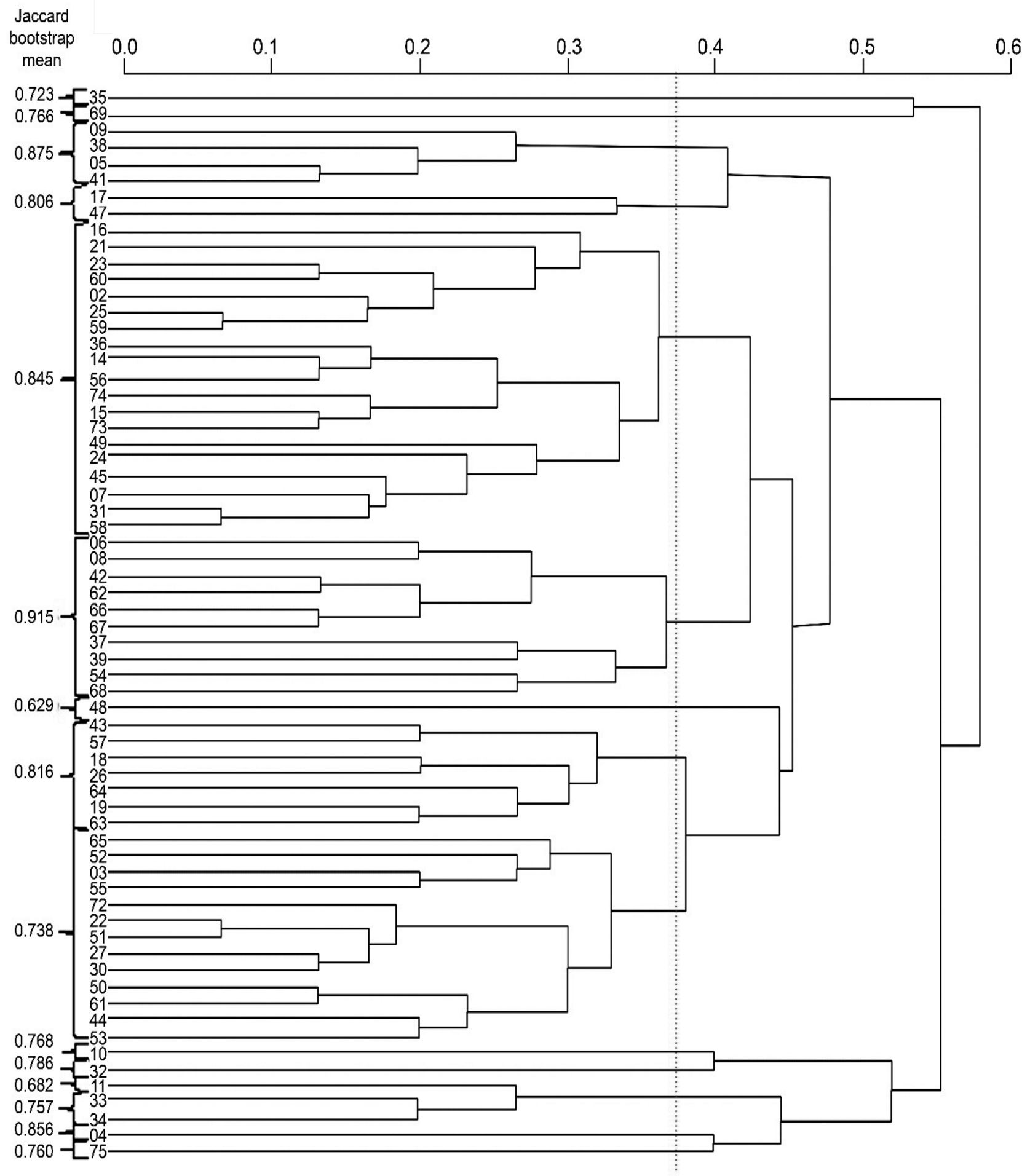


Tocher and UPGMA grouping methods were partially in agreement, allowing grouping 44 of the 65 analyzed accessionsequally. The same results were obtained by Bento et al. (2007), which grouped 19 of the 28 analyzed chili pepperaccessions equally. Tocher and UPGMA methods were also partially coincident in the separation of 137 pepper genotypes from SouthwesternGoiás (Alvares et al., 2012).

Cophenetic correlation coefficient (CCC) can be used to compare clustering results of the same data set, using different distance measures or clustering algorithms. In general, CCC is a measure of how accurately a cluster method preserves the pairwise distances among individuals (Kumar \& Toshniwal, 2016). Both clustering methods showed similar CCC
(0.72 for Tocher and 0.65 for UPGMA) significant at $1 \%$ probability. Furthermore, Jaccard bootstrap method showed that clusters formed by UPGMA were consistent. Both clustering methods should be used in combination, because one statistical approach complements the other.

Traits with less impact on Mean Decrease Impurity (MDI), and respectively with less impact to detect genetic divergence among accessions were endof flowering appendage, calyx margin and calyx pigmentation (Figure 2). Endof flowering appendagewas absent for all formed clusters. Calyx pigmentation was present only in two clusters, for Tocher and UPGMA method. Calyx margin had small variation among clusters, being intermediate or dentate (Tables 3 and 4).

Figure 2. Mean Decrease Impurity of 15 reproductive traits used to evaluate divergence genetic of Brazilian pepper. Monte Carmelo, UFU, 2016.

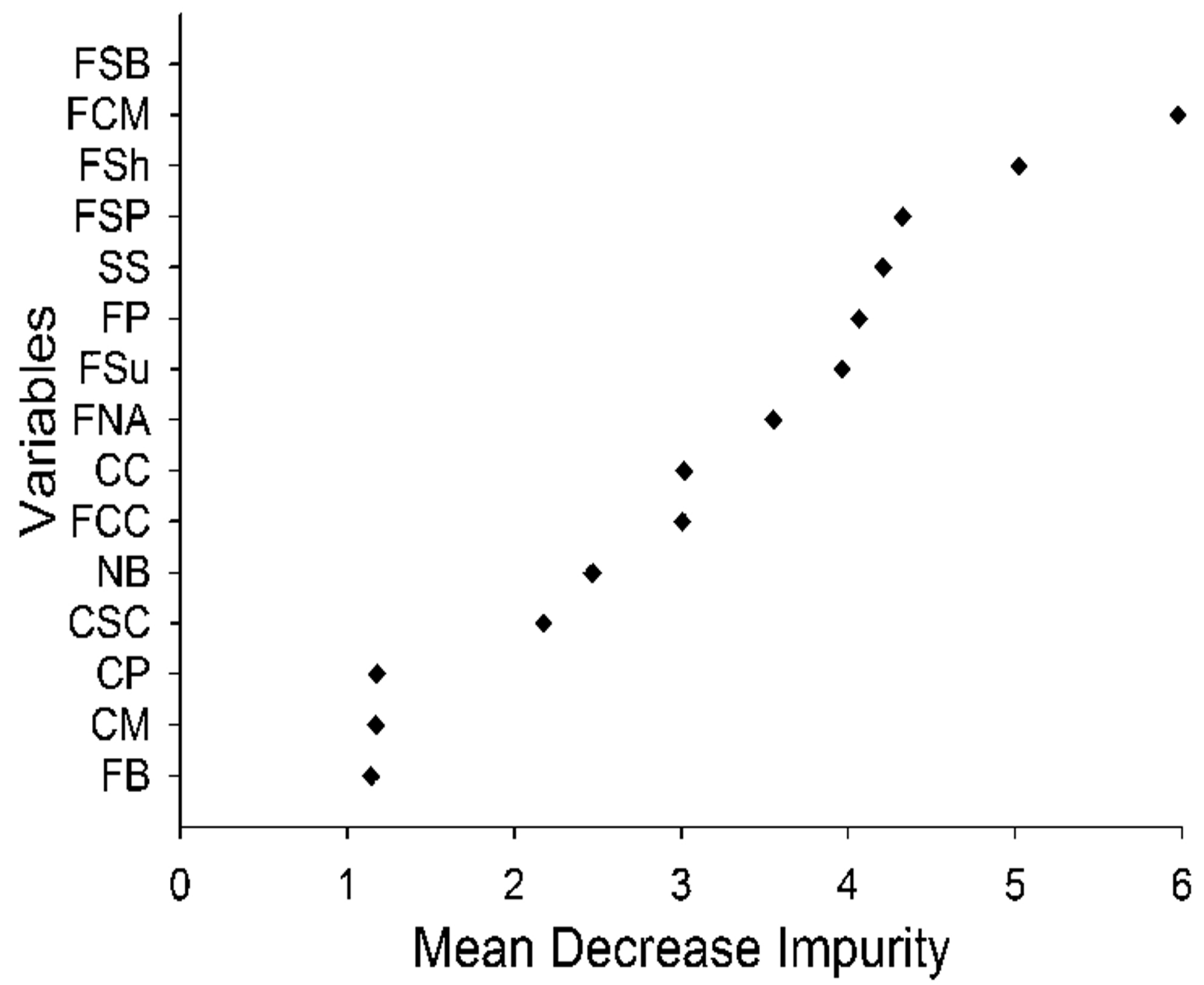

FNA: Number of flowers per axil; FP: Flower position; CC: Corolla color; CSC: Corolla spot color; CP: Calyx Pigmentation; CM: Calyx margin; FCM: Fruit color at mature stage; FSh: Fruit shape; FSP: Fruit shape at pedicel attachment; NB: Neck at fruit base; FSB: Fruit shape at end of flowering; FB: End of flowering appendage; FCC: Fruit cross-sectional corrugation; FSu: Fruit surface; SS: Seed size. 

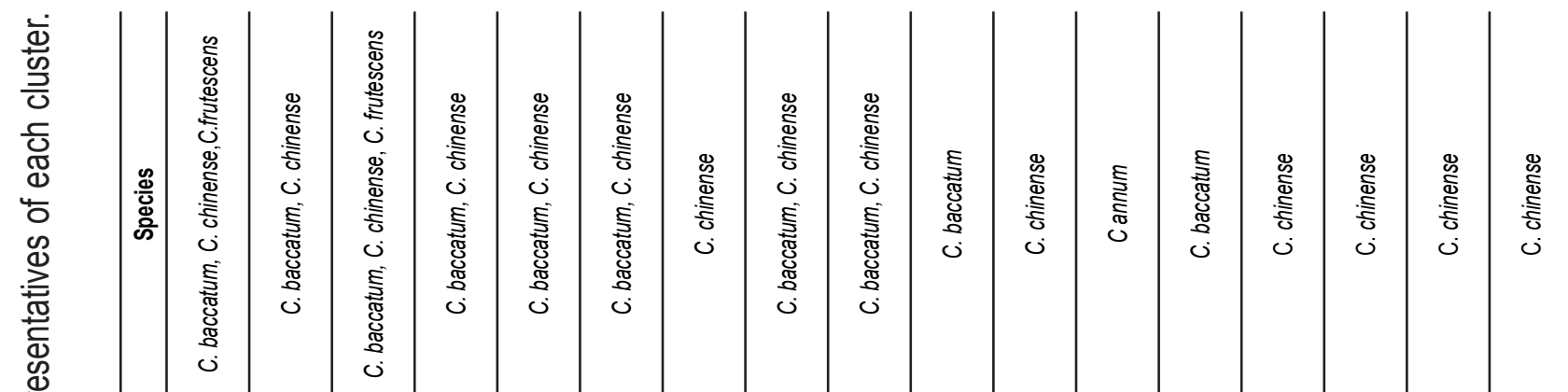

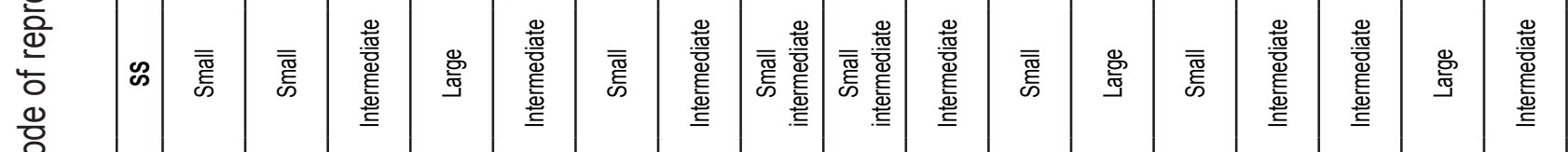

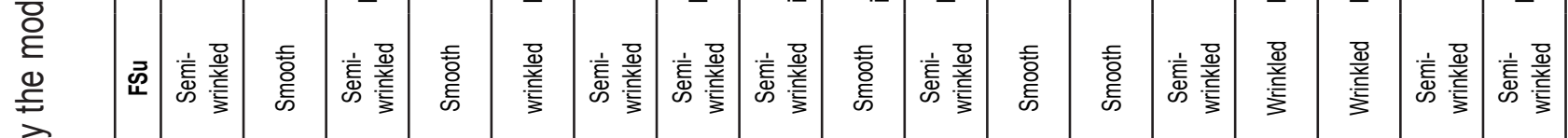

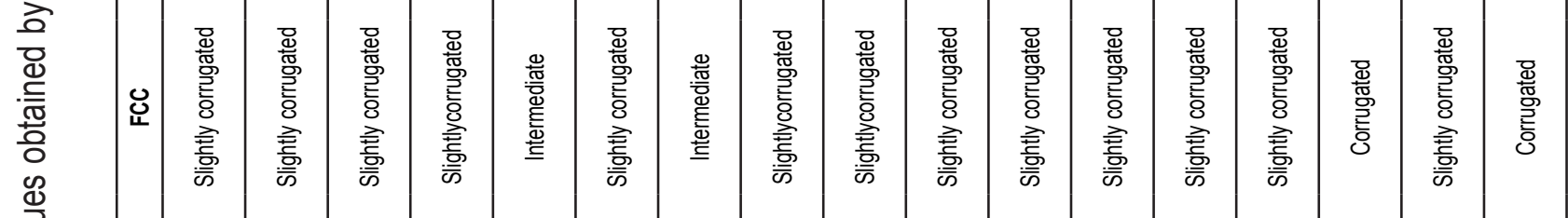

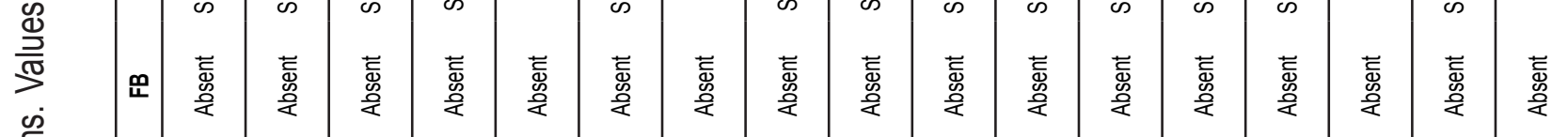

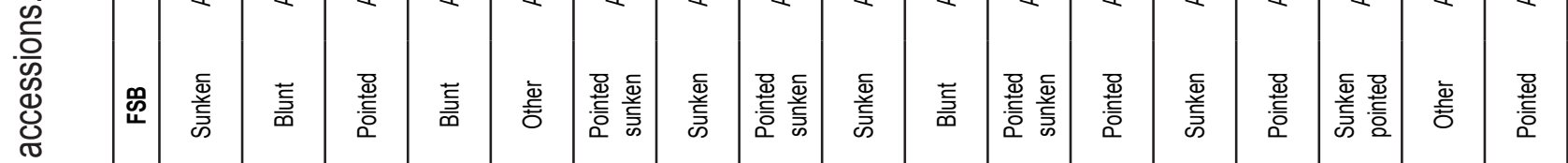

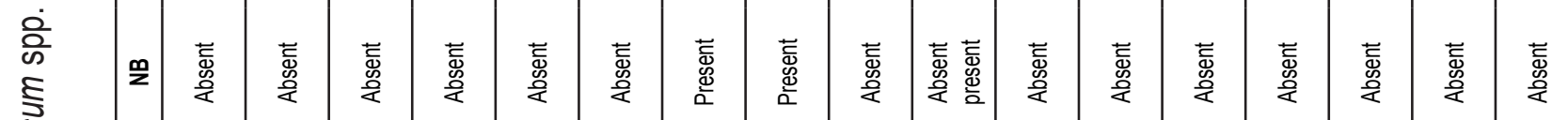

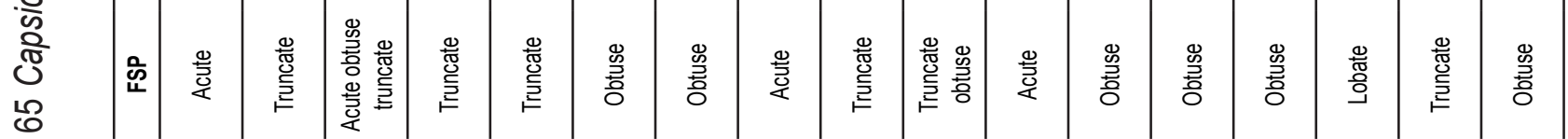

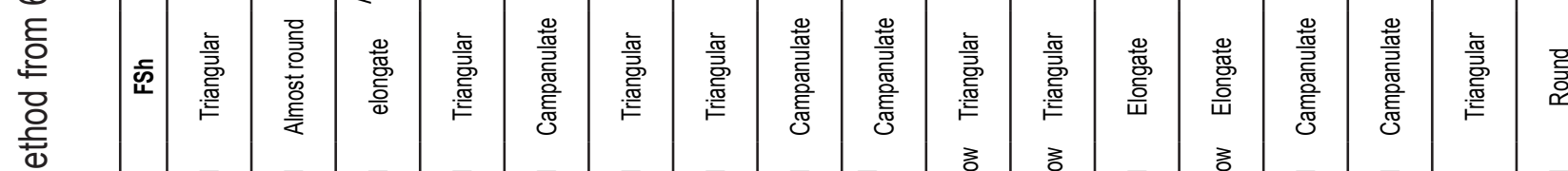

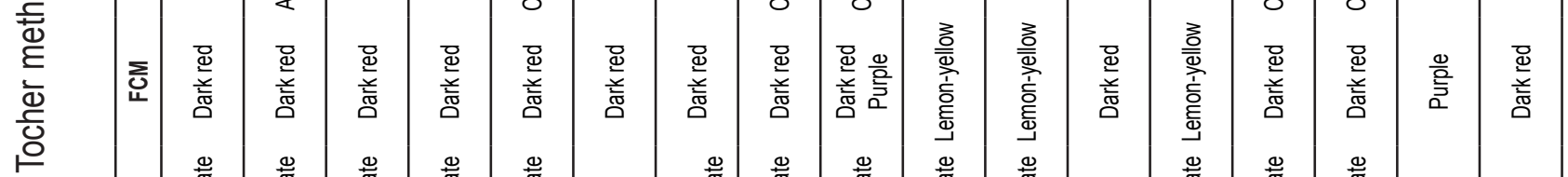

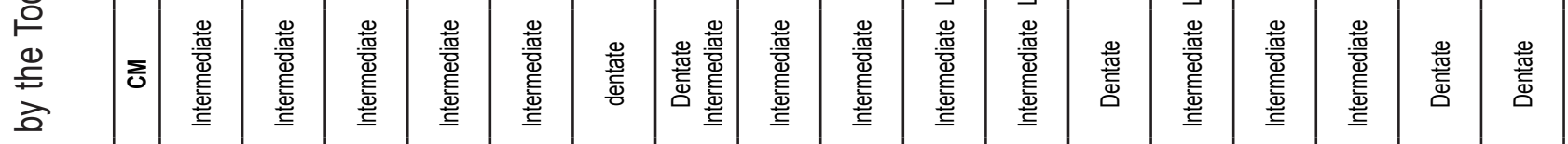

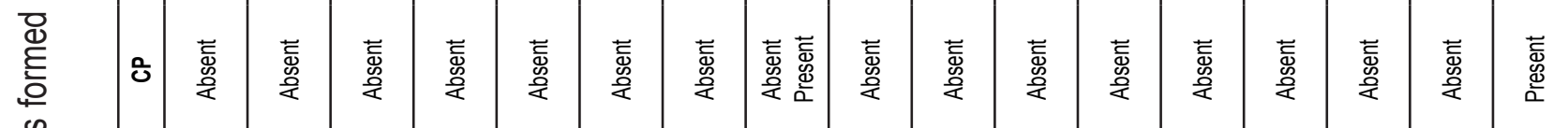

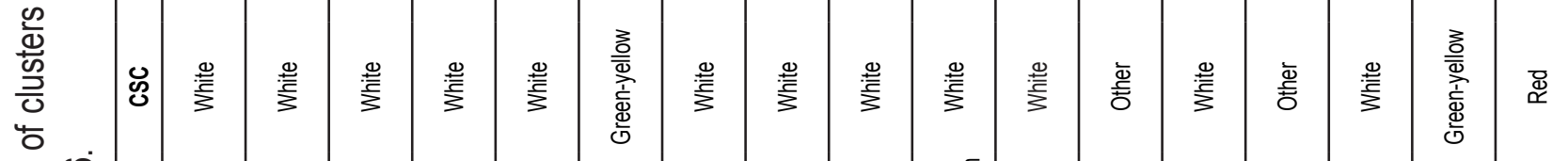

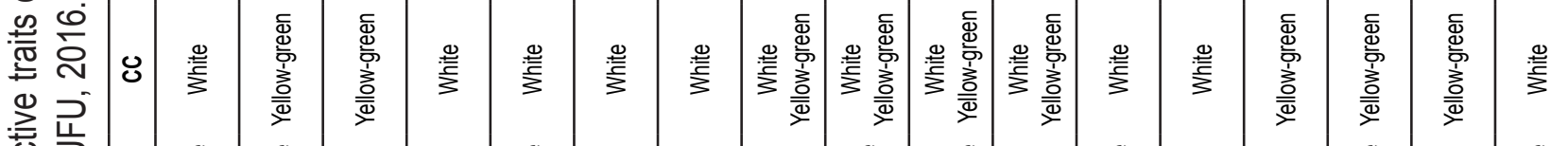

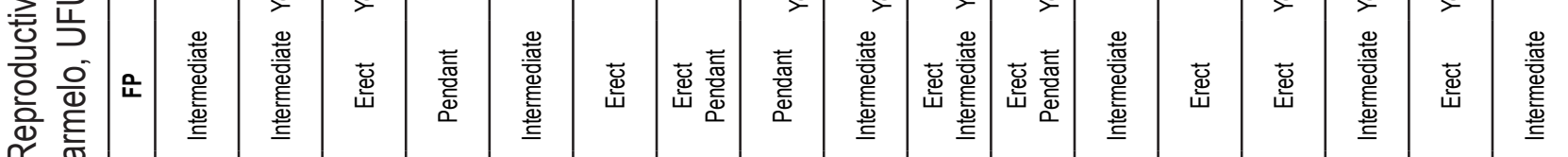

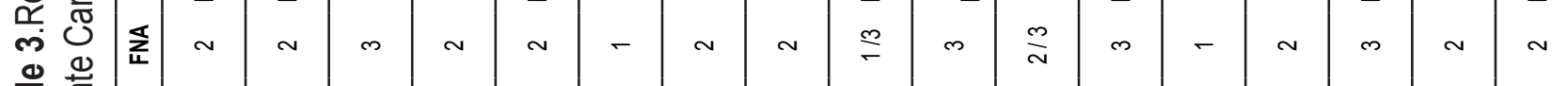
을 
$\frac{\frac{c}{g}}{\Phi}$

童

$\stackrel{90}{ \pm}$

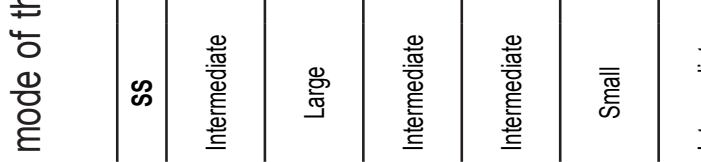

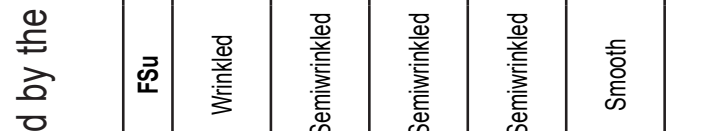

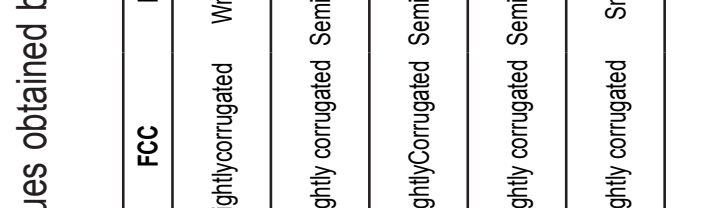

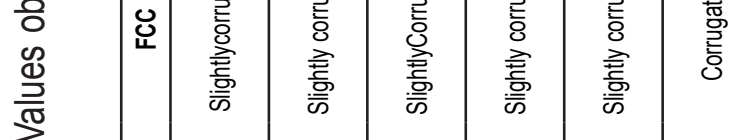

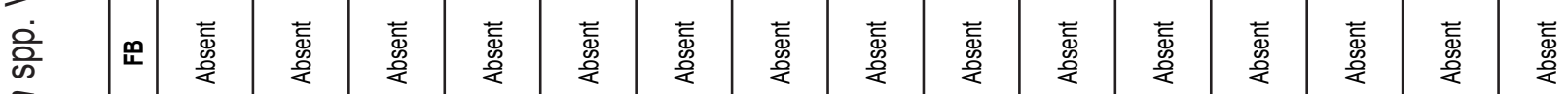

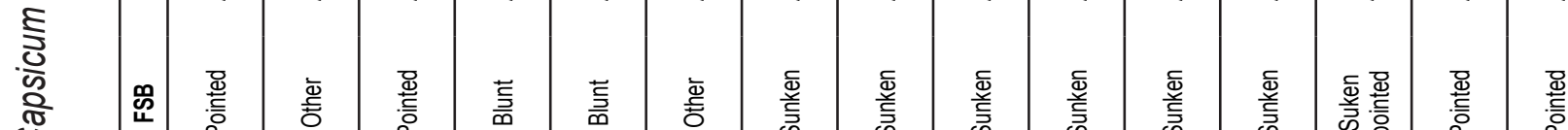
疋

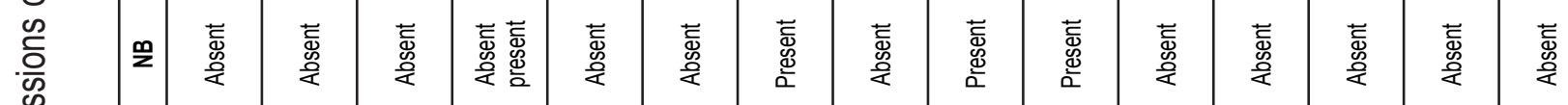

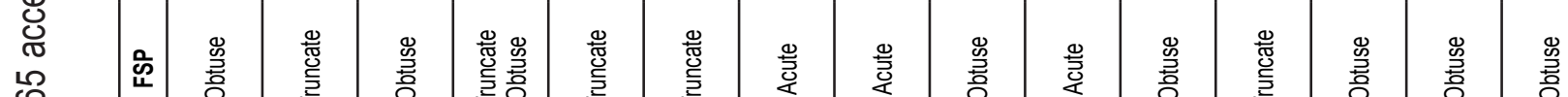

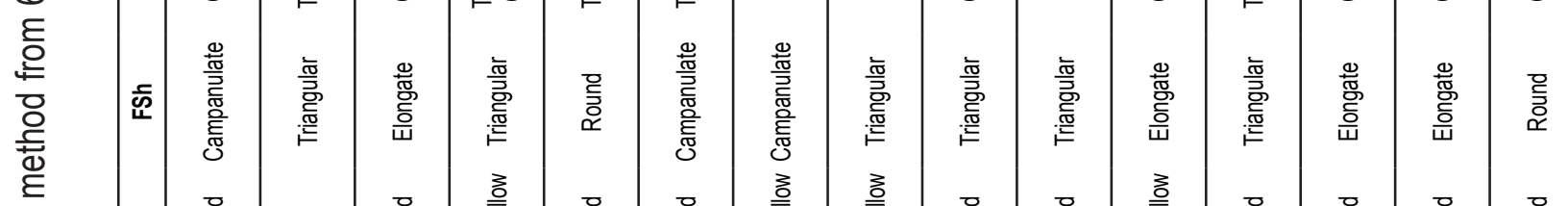

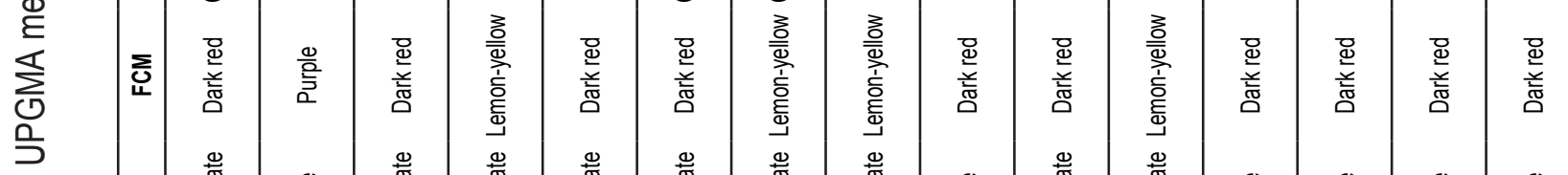

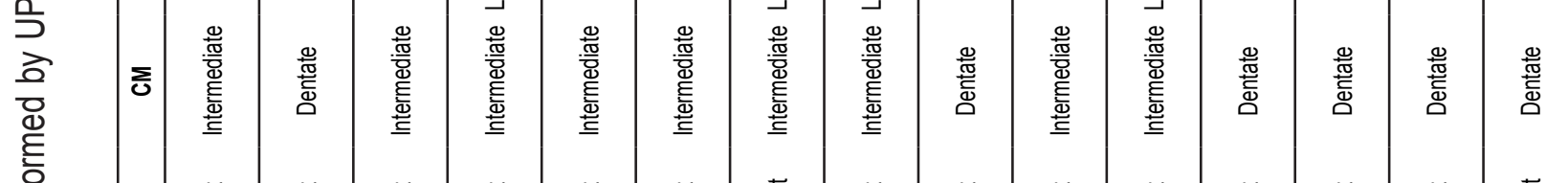

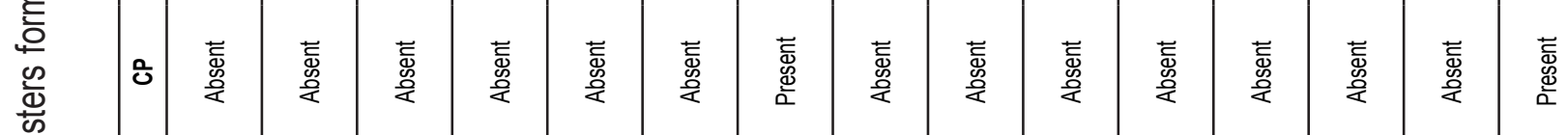

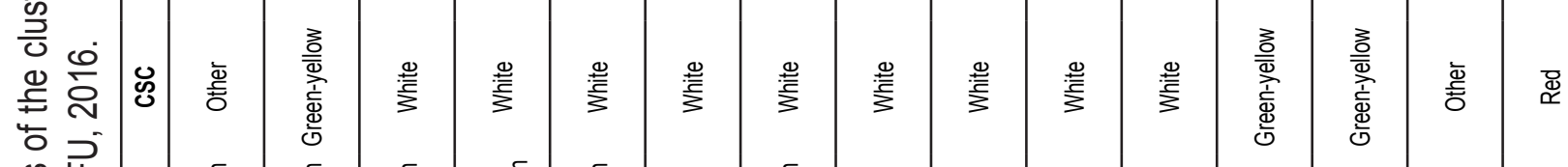

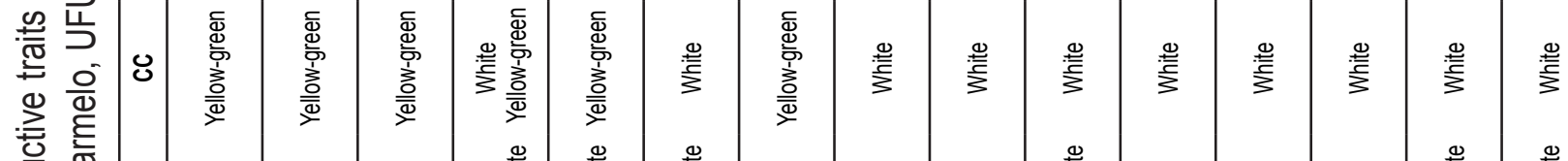

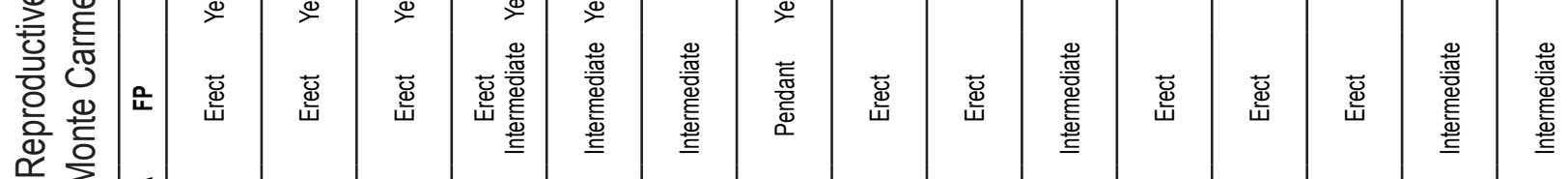

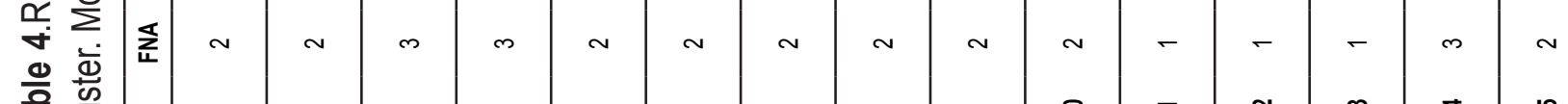

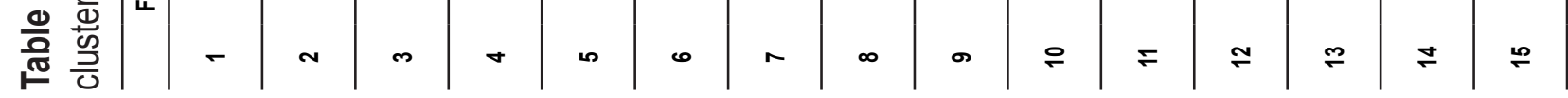


Cramer's V correlation among the 105 intercoefficients presented 22 significant correlations by Chi-Square test at 5\% significance (Table 5). Traits with more correlations were Fruit shape (seven); Fruit shape at pedicel attachment (five); Fruit surface, Flower position, Corolla spot color, Calyx margin, Fruit shape at the endof flowering, Fruit cross-sectional corrugation (four). Fruit color at mature stage and endof flowering appendage had no correlation with any other trait.

Table 5. Cramer's V correlation of 15 reproductivequalitative traits used to detect genetic diversity of pepper. Monte Carmelo, UFU, 2016.

\begin{tabular}{|c|c|c|c|c|c|c|c|c|c|c|c|c|c|c|c|}
\hline Trait & FNA & FP & CC & $\mathrm{CSC}$ & $\mathrm{CP}$ & CM & FCM & FSh & FSP & NB & FSB & FB & FCC & Fsu & SS \\
\hline FNA & - & 0.263 & 0.238 & 0.471 & 0.183 & 0.459 & 0.252 & 0.326 & 0.262 & 0.171 & 0.268 & 0.205 & 0.142 & 0.130 & 0.161 \\
\hline FP & & - & 0.189 & 0.313 & 0.166 & 0.328 & 0.267 & 0.353 & 0.224 & 0.153 & 0.198 & 0.197 & 0.212 & 0.276 & 0.222 \\
\hline $\mathrm{CC}$ & & & - & 0.147 & 0.192 & 0.173 & 0.217 & 0.395 & 0.230 & 0.158 & 0.367 & 0.023 & 0.115 & 0.104 & 0.035 \\
\hline CSC & & & & - & 0.494 & 0.850 & 0.193 & 0.259 & 0.219 & 0.229 & 0.266 & 0.088 & 0.149 & 0.263 & 0.193 \\
\hline $\mathrm{CP}$ & & & & & - & 0.118 & 0.202 & 0.448 & 0.038 & 0.002 & 0.121 & 0.056 & 0.146 & 0.115 & 0.088 \\
\hline CM & & & & & & - & 0.270 & 0.225 & 0.430 & 0.083 & 0.265 & 0.076 & 0.139 & 0.151 & 0.247 \\
\hline FCM & & & & & & & - & 0.276 & 0.267 & 0.205 & 0.284 & 0.135 & 0.256 & 0.226 & 0.285 \\
\hline FSh & & & & & & & & - & 0.442 & 0.331 & 0.485 & 0.330 & 0.473 & 0.517 & 0.245 \\
\hline FSP & & & & & & & & & - & 0.487 & 0.426 & 0.088 & 0.354 & 0.299 & 0.214 \\
\hline NB & & & & & & & & & & - & 0.417 & 0.045 & 0.194 & 0.274 & 0.075 \\
\hline FSB & & & & & & & & & & & - & 0.231 & 0.387 & 0.297 & 0.282 \\
\hline FB & & & & & & & & & & & & - & 0.224 & 0.145 & 0.126 \\
\hline FCC & & & & & & & & & & & & & - & 0.603 & 0.178 \\
\hline Fsu & & & & & & & & & & & & & & - & 0.281 \\
\hline SS & & & & & & & & & & & & & & & - \\
\hline
\end{tabular}

Values in bold represent significant correlation by Chi-Square test. FNA: Number of flowers per axil; FP: Flower position; CC: Corolla color; CSC: Corolla spot color; CP: Calyx Pigmentation; CM: Calyx margin; FCM: Fruit color at mature stage; FSh: Fruit shape; FSP: Fruit shape at pedicel attachment; NB: Neck at base of fruit; FSB: Fruit shape at the end of flowering; FB: End of flowering appendage; FCC: Fruit cross-sectional corrugation; FSu: Fruit surface; SS: Seed size.

On the other hand, fruit shape at the endof flowering and fruit color at mature stage had great contribution to distinguish genotypes, presenting higher MDI values. Large diversity between clusters can be observed for fruit color at mature stage varying between lemon-yellow, dark red, and purple. All fruit shape classes at the endof flowering were observed in clusters (pointed, blunt, sunken, sunken and pointed and others), demonstrating high variation of this genetic trait among accessions. Fruit shape was also detected as one of the most effective descriptors for Capsicum accessions by Costa et al. (2015).

MDI exhibit desirable properties for assessing the relevance of a variable: it is equal to zero only if the variable is irrelevant and depends only on relevant variables (Liaw and Wiener, 2002). MDI also showed that all 15 traits contributed to analyze genetic divergence and should be used in further similar studies. If the number of traits under analysisshould be reduced, Calyx margin and Calyx Pigmentation should be discarded due to their lower reduction on mean impurity and also because Calyx margin was correlated with $\mathrm{FP}$, FNA, CSC and Fsh; and Calyx Pigmentation with CSC. Fruit blossom end appendage also showed lower score on MDI; however, this trait was not correlated with any other variable.

Capsicum spp. Germplasm Bank from UFU has high variability and qualitative reproductive traits were capable of distinguishing genotypes in several clusters. These results are in accordance with other published papers that accessed genetic divergence in peppers of the genus Capsicum (Baba et al., 2015; Maciel et al., 2016; Sudré et al., 2010). The same accessions were used to detect divergence based on the physiochemical characteristics of fruits (Maciel et al., 2016). Unlike this study, genotypes were clustered in only four groups, evidencing that reproductive traits were more variant in the germplasm. Our study also allowed isolating more genotypes. For plant breeders, isolated genotypes represent a possibility of new crossings that could explore maximum heterosis. 
Multicategorical traits have the advantage of easy observation and require less time and labor, being ideal for use in gene bank and collections with short human and financial resources. Moreover, these traits are not affected by the environment. Genetic divergence detected in this paper encourages other researchers to perform the characterization of pepper collections as completely as possible, because it becomes possible to generate more reliable information of the variability and genetic divergence among accessions. Our research discloses the reproductive biodiversity of peppers in 'Alto Paranaíba' and 'TriânguloMineiro' regions and the importance of maintening these genotypes. For users of other pepper collections, there is possibility of using this genetic bank, ensuring new materials for plant breeders.

\section{REFERENCES}

ABCSEM AssociaçãoBrasileira do Comércio de Mudas e Sementes. 2016, June 14. Pesquisa de mercado de sementes de hortaliças. Available at: http://www. abcsem.com.br/dadosdosegmento.php.

Alvares, R.C.; Reis, E.F.; Pinto, J.F.N. Genetic divergence in pepper genotypes from southwest Goiás. Ciência e Agrotecnologia, 2012, 36, 498-506. http:// dx.doi.org/10.1590/S1413-70542012000500002

Baba, V.Y.; Rocha, K.R.; Gomes, G.P.; Ruas, C.F.; Ruas, P.M., Rodrigues, R.; Gonçalves, L.S.A. Genetic diversity of Capsicumchinense accessions based on fruit morphological characterization and AFLP markers. Genetic Resources and Crop Evolution, 2015, 63, 1371138. http://doi.org/10.1007/s10722-015-0325-4

Bento, C.S.; Sudré, C.P.; Rodrigues, R.; Riva, E.M.; Pereira, M.G. Descritoresqualitativos e multicategóricosnaestimativa da variabilidadefenotípica entre acessos de pimenta. Scientia Agraria,2007, 8, 149-156.http://dx.doi.org/10.5380/rsa.v8i2.8379

Büttow, M.V.; Barbiere, R.L.; Neitzke, R.S.; Heiden, G. Diversidadegenética entre acessos de pimentas e pimentões da EmbrapaClimaTemperado. Ciência Rural, 2010, 40, 1264-1269. http://dx.doi.org/10.1590/ S0103-84782010000600004
Bianchi, P.A.; Dutra, I.P.; Moulin, I.M.M.; Santos, J.A.; Santos Júnior, A.C. Morphological characterization and analysis of genetic variability among pepper accessions. Ciência Rural, 2016, 46,1151-1157. http:// doi.org/10.1590/0103-8478cr20150825

Charrad, M.; Ghazzali, N.; Boiteau, V; Nikfans, A. NbClust: An R Package for Determining the Relevant Number of Clusters in a Data Set. Journal of Statistical Software,2014,61, 1-36. http://doi.org/10.18637/jss. v061.i06.

Costa, L.V.; Bentes, J.L.S.; Lopes, M.T.G.; Alves, S.E.M.; Viana Júnior, J.M. Caracterização de acessos de pimentas do Amazonas. HorticulturaBrasileira, 2015, 33, 290-298. http://doi.org/10.1590/S0102053620150000300003

Domenico, C.I.; Coutinho, J.P.; Godoy, H.T.; Melo, A.M.T. Caracterizaçãoagronômica e pungênciaempimenta de cheiro. HorticulturaBrasileira,2012, 30, 466-472.http:// doi.org/10.1590/S0102-05362012000300018

FAOSTAT - Food and Agriculture Organization of the United Nations. 2016, June 26. Available at: http:// faostat.fao.org

Gower, J.C. A general coefficient of similarity and some of its properties. Biometrics,1971,27, 857-874.http:// dx.doi.org/10.2307/2528823

IPGRI - INTERNATIONAL PLANT GENETIC RESOURCE INSTITUTE. Descriptor for Capsicum (Capsicum spp.). International Plant Genetic Resource Institute: Rome, Italy, 1995. 51 p.

Knezovic, Z.; Gunjaea, Z.; Satoviae, F.; Kolak, I. Comparison of Different Methods for Classification of Gene Bank Accessions. Agriculturae Conspectus Scientificus, 2005, 70, p. 87-91.

Kumar, S; Toshniwal, D. Analysis of hourly road accident counts using hierarchical clustering and cophenetic correlation coefficient (CPCC). Journal of Big Data, 2016, 3, 1-11. http://doi.org/10.1186/s40537-016-00463

Liaw, A; Wiener, M. Classification and Regression by random Forest. $R$ News, 2002, 2/3, 18-22. 
Maciel, G.M.; Oliveira, C.S.; Siquieroli, A.C.S.; Melo, E.I.; Oliveira, A.H.G. Genetic dissimilarity among the physiochemical characteristics of fruit from pepper accessions. Bioscience Journal, 2016, 32, 978-985. http://doi.org/10.14393/BJ-v32n4a2016-33893

Moura, M.C.C.L.; Gonçalves, L.S.A.; Sudré, C.P.; Rodrigues, R.; Amaral Júnior, A.A.; Pereira, T.N.S. Algoritmo de Gower naestimativa da divergênciagenéticaemgermoplasma de pimenta. HorticulturaBrasileira, 2010, 28, 155-161.http://dx.doi. org/10.1590/S0102-05362010000200003

Paulus, D.; Valmorbida, R.; Santin, A.; Toffoli, E.; Paulus, E. Crescimento, produção e qualidade de frutos de pimenta (Capsicum annuum) emdiferentesespaçamentos. HorticulturaBrasileira, 2015, 33, 91-100. http://doi.org/10.1590/S0102053620150000100001

Signorini, T.; Renesto, E.; Machado, M.F.P.S.; Bespalhok, D.N.; Monteiro, E.R. Diversidadegenética de espécies de Capsicum com base em dados de isozimas. HorticulturaBrasileira, 2013, 31, 534-539. http://dx.doi.org/10.1590/S0102-05362013000400005
Silva, F.C.S.; Sediyama, T.; Silva, A.F.; Bezerra, A.R.G.; Rosa, D.P.; Ferreira, LV.Identification of new descriptors for differentiation of soybean genotypes by Gower algorithm. African Journal of Agricultural, 2016, 11, 961966, 2016. http://doi.org/10.5897/AJAR2015.10158

Silva,A.R.;Dias,C.T.S.Acopheneticcorrelationcoefficient for Tocher's method. PesquisaAgropecuáriaBrasileira, 2013,48,589-596. http://dx.doi.org/10.1590/S0100$204 \times 2013000600003$

Sudré, C.P.; Gonçalves, L.S.A.; Rodrigues, R.; Riva, E.M.; Amaral Júnior, A.T.; Rivasouza, E.M.; Bento, C.S. Genetic variability in domesticated Capsicum spp. as assessed by morphological and agronomic data in mixed statistical analysis. Genetics and Molecular Research, 2010, 9, 283-294. http://dx.doi.org/10.4238/ vol9-1gmr698

Vasconcelos, C.S.; Barbieri, R.L.; Neitzke, R.S.; Priori, D.; Fischer, S.Z.; Mistura, C.C.Determinação da dissimilaridadegenética entre acessos de Capsicum chinense com base emcaracterísticas de flores. Revista Ceres,2012, 59, 493- 498. http://doi.org/10.1590/ S0034-737X2012000400009 